\title{
Aspectos patológicos e clínicos de uma bezerra Holandesa infectada naturalmente por Tripanosoma sp. na região do Alto Paranaíba/MG
}

Pedro Henrique Vieira Germano;,Alex André da Silva, Gertrud Elisa Campos Edler, Luis Oliveira Lopes

Centro Universitário de Patos de Minas (UNIPAM), Patos de Minas, MG, Brasil

*Autor correspondente

e-mail: pedro.vieira11@yahoo.com.br

\section{Resumo}

A tripanossomíase bovina é uma enfermidade de distribuição geográfica mundial. No Brasil, o agente etiológico mais relevante é o Trypanosoma vivax. 0 estudo visou relatar os aspectos clínico-patológicos da tripanossomíase em um bovino de uma propriedade leiteira do município de Tiros, Minas Gerais. Uma bezerra de 4 meses, Holandesa, foi atendida no Centro Clínico Veterinário do Centro Universitário de Patos de Minas. Ao exame clínico, o animal apresentava apatia, desidratação, anorexia, presença de ectoparasitas, decúbito esternal, anemia e mucosa vulvar apresentando petéquias e equimoses, tempo de preenchimento capilar de 2 segundos, frequência cardíaca de $92 \mathrm{bpm}$, frequência respiratória de $40 \mathrm{bpm}$, hipertermia $\left(40,6{ }^{\circ} \mathrm{C}\right)$ e linfoadenomegalia. À auscultação pulmonar, observou-se presença de estertor discreto. 0 rúmem apresentava hipomotilidade $2 \mathrm{mov} / 5 \mathrm{~min}$. 0 proprietário relatou ter adquirido receptoras. Posteriormente à vacinação de aftosa, as manifestações clínicas apareceram, apresentando casos de óbito. A suspeita principal foi tripanossomíase. 0 diagnóstico foi baseado nos sinais clínicos e no resultado do exame de reação de imunofluorescência indireta (RIFI), o qual foi positivo. Apesar de terem sido empregadas técnicas parasitológicas de diagnóstico, gota espessa, Woo e Buffy coat, não foram encontradas formas tripomastigotas, devido ao tratamento do animal na propriedade com diaceturato de diaminazeno. Além disso, a presença de hemácias parasitadas por Babesia bovis no animal reforça a ideia de alguns autores de que outros hematozoarios podem mascarar o diagnóstico da tripanossomíase. 0 hemograma do animal apresentou anemia microcitica e normocromica, além de anisocitose, policromasia e trombocitopenia. Houve aumento sérico de fosfatase alcalina e gama glutamil trnasferase, enquanto as proteínas totais mostraram-se diminuídas, sugerindo algum tipo de comprometimento hepático. Foi utilizado como tratamento, diaceturato de diminazene na dosagem de $5.5 \mathrm{mg} / \mathrm{kg}$ e flunixin $1.1 \mathrm{mg} / \mathrm{kg}$ a cada 24 horas, durante dois dias, e transfusões sanguíneas. 0 animal veio a óbito. Apesar da infecção não gerar lesões patognomônicas, os principais 
achados macroscópicos foram edema na região da barbela, palidez de carcaça, hidrotorax, líquido ascítico de coloração ictérica, linfoadenomegalia e edematosos. Ademais, hepatoesplenomegalia, fígado amarelado com bordas arredondadas e áreas de esteatose, vesícula biliar repleta. 0 baço apresentava-se de coloração pálida, com cápsula espessa e predomínio de polpa branca. 0 coração tinha presença de fibrina e aderência do pericárdio. Além das aderências pulmonares, o parênquima estava colabado e com fibrose, sugestivo de pleuropneumonia. No rim, verificou-se hemorragia de cápsula renal e ausência de proporção cortical/medular, sugerindo nefrite intersticial multifocal. Os achados de necropsia, de modo geral, assemelham-se aos descritos em um surto de T. vivax em bovinos leiteiros no município de Igarapé. Conclui-se que a tripanossomíase está cada vez mais presente na região do Alto Paranaíba, e que a falta de rotina de diagnóstico e o desconhecimento por parte dos produtores e proprietários é um agravo para a sua ocorrência. 